Stantial, M. L., J. B. Cohen, A. J. Darrah, S. L. Farrell and B. Maslo. 2021. The effect of top predator removal on the distribution of a mesocarnivore and nest survival of an endangered shorebird. Avian Conservation and Ecology. 16(1):8. https://doi.org/10.5751/ACE-01806-160108 Copyright (C) 2021 by the author(s). Published here under license by the Resilience Alliance.

Research Paper

\title{
The effect of top predator removal on the distribution of a mesocarnivore and nest survival of an endangered shorebird
}

\author{
Michelle L. Stantial ${ }^{1}$ (D), Jonathan B. Cohen ${ }^{1}$, Abigail J. Darrah ${ }^{2}$, Shannon L. Farrell ${ }^{1}$ and Brooke Maslo ${ }^{3}$ \\ ${ }^{1}$ Department of Environmental and Forest Biology, State University of New York College of Environmental Science and Forestry, \\ Syracuse, NY, USA, ${ }^{2}$ Audubon Mississippi, Coastal Bird Stewardship Program, Moss Point, Mississippi, USA, ${ }^{3}$ Rutgers, The State \\ University of New Jersey, Department of Ecology, Evolution and Natural Resources, New Brunswick, New Jersey, USA
}

\begin{abstract}
For trophic systems regulated by top-down processes, top carnivores may determine species composition of lower trophic levels. Removal of top predators could therefore cause a shift in community composition. If predators play a role in limiting the population of endangered prey animals, removing carnivores may have unintended consequences for conservation. Lethal predator removal to benefit prey species is a widely used management strategy. Red foxes (Vulpes vulpes) are a common nest predator of threatened piping plovers (Charadrius melodus) and are often the primary target of predator removal programs, yet predation remains the number one cause of piping plover nest loss. Predator exclusion cages (hereafter, exclosures) around nests are often used to keep foxes from eating eggs, as an alternative to predator removal. Fox removals may increase the presence or activity of smaller predators, including American mink (Neovison vison), which can enter exclosures. We predicted that when foxes were removed from plover breeding sites, mesopredator release of mink would occur and lead to increased predation levels of plover nests. Average probability of mink occupancy was higher when foxes were absent $(0.26[95 \% \mathrm{BCI}=0.16,0.38])$ than when they were present $(0.04[0.01,0.09])$. For nests not protected by exclosures, nest predation was similar at sites with $(0.42[0.12,0.68])$ and without foxes $(0.38[0.10,0.64])$. At sites where foxes were absent, however, predation rates of exclosed nests were 3 -fold higher (foxes absent $[0.25\{0.06,0.52\}]$ ) compared to sites where foxes remained $[0.06\{0.01,0.18\}])$. Our results suggest that removal of foxes from plover breeding sites allowed American mink to expand their local range. In turn, removal of foxes led to a decrease in nest survival of an endangered ground-nesting bird. Conservation within complex trophic systems may fail if interactions among species are not well understood when implementing lethal predator removal.
\end{abstract}

\section{Effet de l'élimination d'un supraprédateur sur la répartition d'un mésocarnivore et la survie des nids d'un oiseau de rivage en voie de disparition}

RÉSUMÉ. Dans les systèmes trophiques régulés par des processus descendants, les carnivores de niveaux trophiques supérieurs peuvent déterminer la composition des espèces des niveaux trophiques inférieurs. L'élimination des supraprédateurs pourrait donc entraîner une modification de la composition des communautés. Si les prédateurs jouent un rôle dans la restriction de la population de proies menacées, l'élimination des carnivores peut avoir des conséquences inattendues pour la conservation. L'élimination des prédateurs par voie létale au profit des espèces proies est une stratégie de gestion largement utilisée. Le Renard roux (Vulpes vulpes) est un prédateur commun des nids de Pluviers siffleurs (Charadrius melodus), une espèce menacée, et il fait souvent l'objet de programmes d'élimination, mais la prédation reste la cause première de destruction des nids des pluviers. Les cages d'exclusion de prédateurs (ci-après, les exclos) installées autour des nids sont souvent utilisées pour empêcher les renards de manger les oeufs, comme alternative à l'élimination des prédateurs. L'élimination des renards peut entraîner l'augmentation de la présence ou de l'activité de prédateurs plus petits, dont le Vison d'Amérique (Neovison vison), qui peut entrer dans les exclos. Nous avons prédit que lorsque les renards étaient éliminés des sites de nidification des pluviers, une hausse des mésoprédateurs, les visons, se produirait et conduirait à une augmentation de la prédation des nids de pluviers. La probabilité moyenne d'occurrence du vison était plus élevée lorsque les renards étaient absents $(0,26[95 \%$ ICB $=0,16,0,38])$ que lorsqu'ils étaient présents $(0,04[0,01,0,09])$. Pour les nids non protégés par des exclos, la prédation était similaire sur les sites avec $(0,42[0,12,0,68])$ ou sans renards $(0,38[0,10,0,64])$. Cependant, aux sites où les renards étaient absents, le taux de prédation des nids avec exclos était 3 fois plus élevé (renards absents $[0,25\{0,06,0,52\}]$ ) qu'aux sites où les renards étaient présents [0,06 \{0,01, $0,18\}]$ ). Nos résultats indiquent que l'élimination des renards des sites de nidification du pluvier a permis aux visons d'étendre leur aire de répartition locale. Du coup, l'élimination des renards a entraîné une diminution de la survie des nids d'un oiseau en voie de disparition et nichant au sol. La conservation au sein de systèmes trophiques complexes peut échouer si les interactions entre les espèces ne sont pas bien comprises au moment de la mise en oeuvre de l'élimination des prédateurs par voie létale.

Key Words: American mink; endangered species; habitat use; mesopredator release hypothesis; multispecies occupancy; piping plover; red fox; trophic cascade 


\section{INTRODUCTION}

Understanding how removal of top predators from an ecosystem may affect conservation goals is important because trophic cascades can lead to population declines and/or extinction of species (Palomares et al. 1995, Sovada et al. 1995, Rogers and Caro 1998, Chalfoun et al. 2002). One potential component of a trophic cascade is mesopredator release, in which the loss of high-level predators increases abundance of lower level predators with consequential effects on prey populations (Soulé et al. 1988). Mechanisms of mesopredator suppression may be behavioral (i.e. avoidance; Lima 1998) or due to intraguild predation by apex predators (Russel et al. 2009), which can influence the habitat use and distribution of smaller predators. For example, coyotes are known to kill sympatric fox species (Donadio and Buskirk 2006), whereas red foxes use cover types avoided by coyotes as a partitioning strategy (Gosselink et al. 2003). When changes to the predator community occur due to the decline or removal of dominant predators from the ecosystem, mesopredator release may occur with detrimental effects on prey animals (Myers et al. 2007, Letnic et al. 2012). Information regarding the complexity of species interactions and the trophic consequences of removing dominant predators to improve recovery of endangered species remains poorly understood.

Controlling predators has become a common tool for the maintenance of populations of endangered species. Predation of nests and young is one of the primary limiting factors of endangered birds (Vickery et al. 1992, Berry and Taisacan 2008, Vanderwerf 2012). Human activities have caused changes in the abundance and distribution of potential predators both indirectly (e.g., through landscape alteration and food subsidies) and directly (e.g., through transport of domestic animals; Boarman 2003, Fischer et al. 2012), creating nearly insurmountable challenges to avian conservation. The removal of top predators - by culling or translocation - from ecosystems (Smith et al. 2010) was first implemented to increase nesting success of waterfowl and other ground-nesting game birds (Balser et al. 1968). More recently, wildlife managers have used predator removal to increase nesting success of endangered bird species where predation has become a serious impediment to recovery (Neuman et al. 2004). Generally, when predators are removed from the landscape, avian population sizes tend to increase in response (Côté and Sutherland 1997, Holt et al. 2008, Smith et al. 2010). However, predator removal programs may also change the predator community structure (Johnson and Sargeant 1977) or target an inappropriate trophic level (Rayner et al. 2007), leading to inadvertent increases in nest predation rates.

Complex trophic interactions may lead to unpredictable outcomes for predator removal to benefit endangered prey species. Outcomes of predator control to benefit nesting birds can differ depending upon the type of predators, intensity of predation, degree of predator control, and prey species being impacted (Wagner et al. 1965, Smith et al. 2010). Studies have demonstrated predator control is ineffective on species recovery where only one predatory species was removed (NYS DEC 1951, Clark et al. 1995). However, other studies have reported increased survival and higher productivity of birds when predator control was applied to both avian and mammalian predators (Littlefield 2003, Lavers et al. 2010, Smith et al. 2010). Removal of one predator species may be ineffective due to competitive release of intermediate predators (Ruscoe et al. 2011), which potentially supports the mesopredator release hypothesis.
Predator removal has been employed as a management tool to increase productivity of the federally threatened Atlantic Coast Piping Plover (Charadrius melodus), which nests on beaches and barrier islands from Newfoundland to North Carolina (USFWS 1996, 2020). Predator species of Piping Plover eggs and chicks tend to be generalists with wide distributions that respond favorably to the presence of humans (Marzluff and Neatherlin 2006, Bino et al. 2010). Specifically, red foxes (Vulpes vulpes) have been identified as the top predator in many parts of the breeding range (Patterson et al. 1991, Cohen et al. 2009) and have been targeted for predator removal efforts at many locales. Yet, despite the economic effort dedicated to predation managementbetween \$2-3 million are spent annually for on-site recovery efforts for this population (Hecht and Melvin 2009) — predation remains a serious threat to recovery for Piping Plovers throughout their range(USFWS 2020). Thus, removal of red foxes as a top predator may not lead to desired conservation outcomes. An alternative strategy, placing a wire predator exclosure cage around nests, has been used extensively in lieu of or in addition to removal of predators (Melvin et al. 1992, Estelle et al. 1996). These "exclosures" have been demonstrated to increase nest survival greatly, but do not provide protection for chicks, which leave the nest bowl hours after hatching and do not return to the nest. In addition, smaller predators such as American mink (Neovison vison) may be able to get inside the exclosures and depredate eggs (Nol and Brooks 1982). Thus, examining dynamics among top predators, mesopredators, and plovers in a system with both predator removal and predator exclosures provides an opportunity to examine mesopredator release.

Because Piping Plover abundance and reproductive success can be limited by predation, it is important to gain a better understanding of the management strategies used to mitigate the impacts of predators. We tested the interaction between red fox (hereafter, fox) and American mink (hereafter, mink) at beaches with breeding Piping Plovers where foxes are the dominant predator and are routinely removed. We used a two-species occupancy model, where the probability of occupancy for one species (mink) is conditional upon the presence of a dominant species (fox; Richmond et al. 2010, Rota et al. 2016). We expected that if mesopredator release was occurring, mink occupancy would increase in the absence of foxes as mink move into areas when foxes are no longer present. Furthermore, we examined the relationship between fox occurrence and demographic rates for Piping Plovers. We studied daily nest survival of Piping Plovers from 2015-2017 at sites where the presence of foxes varied. We expected that if mesopredator release were not occurring, complete fox removal would result in decreased nest predation rates. Alternatively, if mesopredator release were occurring, then fox removal would have no quantifiable impact on demographic rates.

\section{METHODS}

\section{Study Area}

Our study occurred from 2015-2017 at 8 sites on barrier islands in southern New Jersey (Fig. 1). Our study area spanned from Barnegat Lighthouse State Park (latitude $39.75^{\circ} \mathrm{N}$, longitude $-74.09^{\circ} \mathrm{W}$ ) to Cape May Point State Park (latitude $38.93^{\circ}$, longitude $-74.95^{\circ}$ ) encompassing approximately 670 ha of coastal dunes, beaches, and maritime forests. Ocean beaches on New 
Jersey barrier islands are characterized by open, sandy areas with sparse vegetation and both natural and human-modified sand dunes. Piping plover nesting areas are often characterized by storm-created landscapes whereby vegetation is scoured by tidal flooding and bayside intertidal sand flats are created (USFWS 1996). However, coastal storms often do not form overwashes in areas that are backed by human development, leaving plovers to nest in poorer quality habitat next to human development and without access to bayside intertidal sand flats. Because red foxes are a generalist species with behavioral plasticity, they can be found in both natural and residential parts of New Jersey barrier islands, using small burrows in dune systems, maritime forests, or under human structures as denning sites (Larivière and Pasitschniak-Arts 1996). American mink are a semi-aquatic species that inhabits the tidal salt marshes adjacent to barrier islands, using wrack (i.e., debris deposited at high tide) on salt marsh edges to build nests (Peeples 2001) and opportunistically foraging in adjacent habitats such as marsh creeks, mudflats or beaches (Gorga 2012).

Fig. 1. Locations of study sites for predator habitat use in piping plover (Charadrius melodus) nesting areas in New Jersey, USA, 2015-2017. Study sites are labeled as follows: BALI, Barnegat Lighthouse States Park; HOLG, Holgate Unit, E.B. Forsythe NWR; NBNA, North Brigantine Natural Area; MWMA, Malibu Beach Wildlife Management Area; AVDU, Avalon-Dunes; SHPT, Stone Harbor Point; NOWI, North Wildwood; CMPSP, Cape May Point State Park.

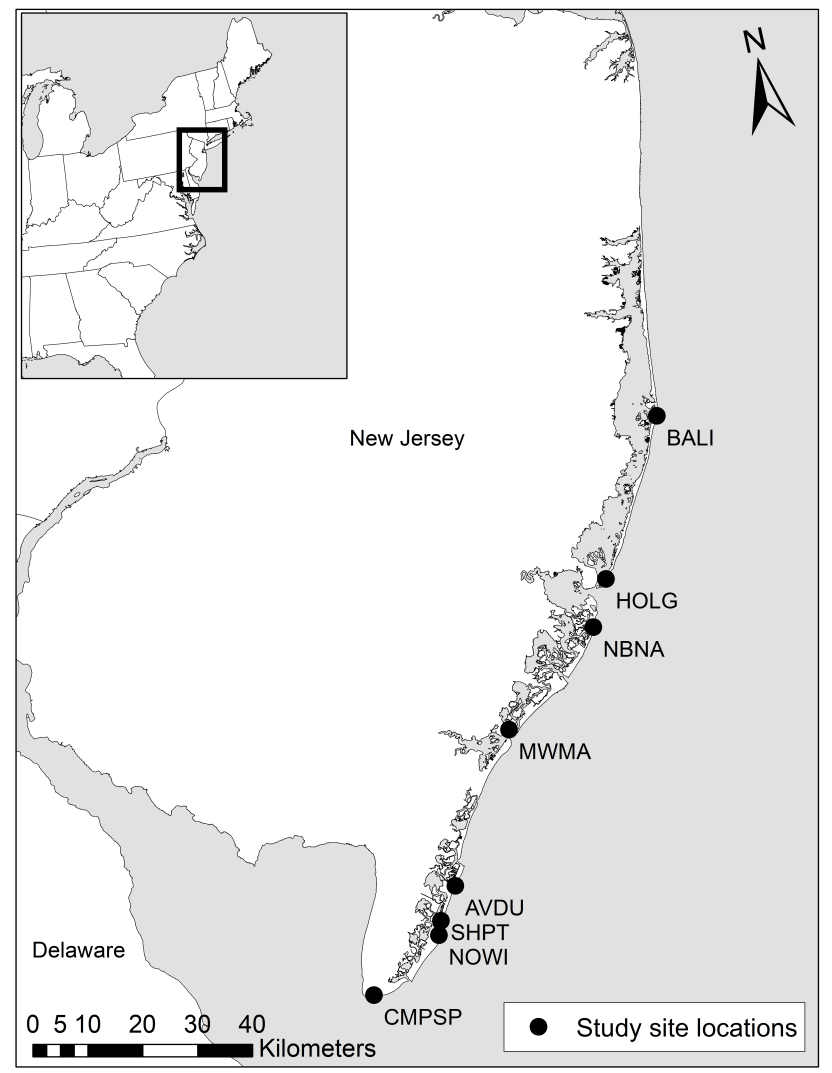

Study sites included Barnegat Lighthouse State Park, Barnegat Light (BALI); Holgate Unit, E.B. Forsythe National Wildlife Refuge, Long Beach Township (HOLG); North Brigantine Natural Area, Brigantine (NBNA); Malibu Wildlife Management Area and Seaview Harbor Marina, Longport (MWMA); AvalonDunes, Avalon (AVDU); Stone Harbor Point, Stone Harbor (SHPT); North Wildwood Beach, North Wildwood (NOWI); and Cape May Point State Park and South Cape May Meadows, Cape May Point (CMPSP). We chose study sites to represent a variety of habitat configurations that consisted of differing arrangements of nesting habitat and varying levels of human use (Table 1). For example, NBNA, HOLG, and SHPT are located at the north or sound ends of barrier islands further from human development and consist of sparsely vegetated dunes and large overwash fans, whereas AVDU, BALI, and NOWI experienced high levels of human disturbance and were linear beaches with humanmodified dune systems. Because landownership varied among study sites from non-governmental organization properties to municipal sites to federal lands, predator removal strategies also varied among study sites. For example, predator removal was not conducted at some sites, federal contractors carried out consistent predator removal on other sites, and in-house predator removal efforts were conducted for the remaining sites.

\section{Occupancy Modeling}

We used repeated predator track surveys to determine the spatial distribution of red foxes and American mink in Piping Plover nesting habitat. Survey plots were selected with the aim of distributing plots across all major beach-dune regions of the study area. To generate predator survey plots, we downloaded the 2012 Land Use/Land Cover Map for New Jersey (NJDEP/OIRM/ BGIS 2015), then uploaded the GIS data into ArcMap (ArcGIS 10.1). We used the random point generator in ArcMap to place random points $50-200 \mathrm{~m}$ apart within cover types that best represented Piping Plover habitat. We chose $50 \mathrm{~m}$ as our minimum distance between survey plots to provide adequate spatial coverage of the site while maintaining independence among points, and $200 \mathrm{~m}$ as the maximum distance, which represented half the distance of the widest stretch of open, sandy beach at our study sites. During the first survey period of the study, we ground-truthed each survey plot location and marked the plot with a wooden stake for ease of navigation in future surveys. We removed plots in cover types where predator tracking would not be feasible such as forested areas, thick vegetation or saltmarsh, and plots were removed or added throughout the study as vegetation encroached on survey plots used in previous years. Points that remained contained substrates where predator tracking would be practicable (i.e., open sandy beach, sparsely vegetated dunes and mudflats).

We conducted surveys at each plot between 15 April-15 August every 2 weeks to ensure tracks would not persist between survey periods and following at least $24 \mathrm{hr}$ of good weather (i.e., wind $<10 \mathrm{kph}$, no rain within $24 \mathrm{hr}$ ) to optimize tracking conditions. Tracks were identified by experienced surveyors who were trained specifically in track identification by an expert. Further, surveyors were able to reference a field guide in circumstances where tracks might have been difficult to identify (Elbroch 2003). We recorded all predator tracks within a $10-\mathrm{m}$ radius of the plot center (Fig. A1.1). We tied a 10-m long string to the wooden stake marking 
Table 1. Locations, study site area, number of survey plots, and number of foxes removed at piping plover (Charadrius melodus) nesting sites for red fox (Vulpes vulpes) and American mink (Vulpes vulpes) occupancy modeling in New Jersey, USA, 2015-2017.

\begin{tabular}{|c|c|c|c|c|c|c|c|c|c|}
\hline \multirow[t]{2}{*}{ Site } & \multirow[t]{2}{*}{ Site ID } & \multirow[t]{2}{*}{ Latitude } & \multirow[t]{2}{*}{ Longitude } & \multirow[t]{2}{*}{ Landscape } & \multirow{2}{*}{$\begin{array}{l}\text { Area of } \\
\text { sandy } \\
\text { substrate } \\
\text { (ha) }\end{array}$} & \multirow{2}{*}{$\begin{array}{l}\text { Number } \\
\text { of survey } \\
\text { plots }\end{array}$} & \multicolumn{3}{|c|}{$\begin{array}{l}\text { Annual number of } \\
\text { foxes removed }\end{array}$} \\
\hline & & & & & & & 2015 & 2016 & 2017 \\
\hline Barnegat Lighthouse State Park & BALI & 39.76032 & -74.09947 & $\begin{array}{l}\text { Barrier Island/ } \\
\text { Inlet }\end{array}$ & 58.05 & 8 & 3 & 0 & 0 \\
\hline Holgate Unit, E.B. Forsythe NWR & HOLG & 39.51765 & -74.28113 & $\begin{array}{l}\text { Barrier Island/ } \\
\text { Inlet }\end{array}$ & 101.25 & 24 & 2 & 4 & 2 \\
\hline North Brigantine Natural Area & NBNA & 39.44482 & -74.32929 & $\begin{array}{l}\text { Barrier Island/ } \\
\text { Inlet }\end{array}$ & 56.85 & 16 & 5 & 5 & 7 \\
\hline Malibu Beach Wildlife Management Area & MWMA & 39.3107 & -74.55052 & Barrier Island & 7.58 & 9 & 2 & 4 & 2 \\
\hline Avalon-Dunes & AVDU & 39.07918 & -74.73201 & Barrier Island & 25.14 & 6 & 3 & 7 & 6 \\
\hline Stone Harbor Point & SHPT & 39.02831 & -74.77754 & Inlet & 61.2 & 18 & 3 & 3 & 3 \\
\hline North Wildwood & NOWI & 39.00583 & -74.78819 & Inlet & 7.91 & 3 & 0 & 0 & 0 \\
\hline Cape May Point State Park & CMPSP & 38.93228 & -74.94828 & Mainland & 25.02 & 6 & 0 & 0 & 0 \\
\hline
\end{tabular}

the center point, then walked a circle around the wooden stake to provide an outline for the $20-\mathrm{m}$ plot diameter.

Given that a plot was within the home range of a fox or mink, our detection of its tracks depended on: 1) whether the predator used that part of its home range just prior to our survey; and 2) if it did, whether we were able to discern and correctly identify its tracks. If we were unable to identify a track within a plot with $100 \%$ certainty, we recorded the track as unknown mammal, and these tracks were not included in our occupancy model. Because we attempted to complete surveys only during periods of good weather, we did not include weather covariates in our detection model.

We used a single season, conditional two-species occupancy model (Richmond et al. 2010, Rota et al. 2016) to estimate the occupancy probability of foxes and mink. Random temporary emigration of a species between surveys was possible; therefore, we interpreted our occupancy parameter as the probability of habitat use rather than occupancy (Kendall et al. 2013). We included year and distance to dune covariates in the fox occupancy model based on prior information on fox occupancy in our study system (Stantial et al. 2020); however, because data were sparse for mink, the only covariate included in the mink occupancy model was fox occupancy. We generated predicted values for $\Psi^{\mathrm{A}}$ $=$ probability of occupancy for foxes, $\Psi^{\mathrm{BA}}=$ probability of occupancy for mink when foxes are present, $\Psi^{\mathrm{Ba}}=$ probability of occupancy of mink when foxes are absent, $\mathrm{p}^{\mathrm{A}}=$ probability of detection for foxes, and $\mathrm{p}^{\mathrm{B}}=$ probability of detection for mink.

\section{Nest Survival}

In our study region, managers often placed wire exclosure fences around plover nests to minimize predation rates (Melvin et al. 1992). We therefore used different traps to capture plovers at nests with no exclosure than at exclosed nests. For nests with no exclosures, we captured adult plovers using walk-in funnel traps at active nests (Cairns 1977), whereas for exclosed nests we blocked $75 \%$ of the base of the exclosure with $0.6 \mathrm{~m}$-tall chicken wire, leaving an exit into a mist-net funnel (J. Cohen, unpublished data). We uniquely marked adult Piping Plovers with either two colored Darvic leg bands (model XCLD, internal diameter $3.1 \mathrm{~mm}$, AVINET, Dryden, New York) on each tibiotarsus or a combination of a Darvic leg band on one tibiotarsus and a multilayered impact acrylic coded flag (internal diameter $3.1 \mathrm{~mm}$, Interrex, Lodz, Poland) on the opposite tibiotarsus, depending on the study site.

Field technicians assessed nest status (i.e., active, hatched, depredated, overwashed, abandoned, buried, or lost to unknown cause; Table A1.1) every 1-7 days. When a nest was lost, renesting attempts for pairs were identified based on unique adult band combinations. We modeled the probabilities of different nest fates (survival, predation, abandonment, weather) as a function of fox presence (a binary variable based on whether presence was documented at least once during the pre-nesting or incubation period [4 May-28 June] during occupancy surveys; Fig. 2) using logistic exposure models (Shaffer 2004) extended to the multinomial form (Darrah et al. 2018). We also included an effect of nest exclosures and an interaction between exclosures and fox presence because exclosures should reduce nest predation to near zero if predators cannot get inside, but it may be above zero if predators can. Baseline probabilities of nest predation and effectiveness of exclosures may depend on site-specific factors; therefore, we included a random site intercept for the linear predictor for predation in our nest fate model.

\section{Statistical Analysis}

All analyses were conducted in R 3.6.2 (R Core Team 2019). We analyzed occupancy probability and nest survival in a Bayesian framework by specifying models in the BUGS language, with posterior distributions for parameters of interest estimated using Markov Chain Monte Carlo (MCMC) simulation with Gibbs sampling as implemented in JAGS v. 3.4.0 (Plummer 2013), called from program R via the package jagsUI (Kellner 2017). We used wide non-informative priors for all parameters. We checked for convergence of 3 parallel MCMC chains per model by visually inspecting the trace plots and by using the Brooks-Gelman-Rubin diagnostic (Gelman 2004); we considered convergence to be achieved at $<1.1$ for all parameters. We deemed covariates to be important predictors if the $95 \%$ credible intervals on the regression parameter did not overlap zero (Kuo and Mallick 1998, Link and Barker 2006). All predictor variables were centered and standardized to improve convergence. 
Fig. 2. Number of detections of red fox, Vulpes vulpes (FOX) and American mink, Neovison vison (MINK) at each study site in New Jersey, USA, 2015-2017. The 4 survey periods and their date ranges included: pre-nesting, 15 April - 3 May; incubation, 4 May - 31 May; chick rearing, 1 June - 28 June; and chick fledging, 29 June - 26 July. Study sites are labeled as follows: BALI, Barnegat Lighthouse States Park; HOLG, Holgate Unit, E.B. Forsythe NWR; NBNA, North Brigantine Natural Area; MWMA, Malibu Beach Wildlife Management Area; AVDU, Avalon-Dunes; SHPT, Stone Harbor Point; NOWI, North Wildwood; CMPSP, Cape May Point State Park. We modeled the probabilities of different nest fates as a function of whether fox presence was noted at least once during the pre-nesting or incubation period [4 May-28 June].

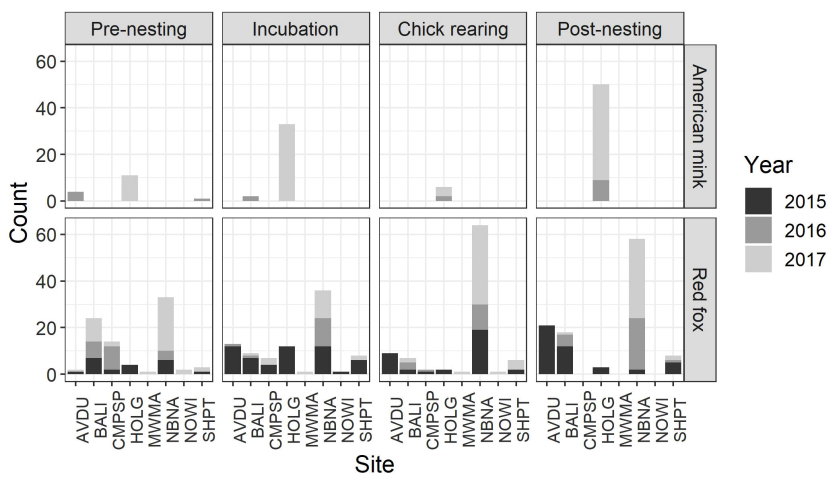

\section{RESULTS}

\section{Occupancy Modeling}

We conducted 24 mammalian predator track surveys at 90 plots among 7 study sites between 15 April-15 August in 2015-2017. We conducted 8 mammalian predator track surveys at 60 plots in 2015, 8 mammalian predator track surveys at 64 plots in 2016, and 8 mammalian predator track surveys at 68 plots in 2017 . We had a total of 373 fox detections and 107 mink detections across years and study sites (Fig. 2). All red foxes were removed from HOLG in 2016 and 2017 and SHPT in 2016 (NJENSP, pers. comm.). Occupancy probability for foxes was $0.80[95 \% \mathrm{BCI}=$ $0.61,1.00]$ in $2015,0.31$ [0.20, 0.43] in 2016, and 0.58 [0.45, 0.71] in 2017. Fox occupancy decreased with distance to the nearest primary dune but the relationship was not significant based on the $95 \%$ BCI on the regression coefficient (Table 2). Mink occupancy probability when foxes were absent was 0.26 ([0.16, $0.38]$ ), which was more than 8 times the average occupancy probability when foxes were present $(0.04$ [0.01, 0.09]); Fig. 3). Detection probability for foxes was $0.33[0.29,0.38]$ and mink detection probability was $0.28[0.20,0.35]$.

\section{Nest Survival}

Nearly half (49.4\%) of the 116 known Piping Plover nest attempts at sites where foxes were present were successful (i.e., at least one egg hatched), compared to $43.3 \%$ of 125 nest attempts at sites where foxes were absent (Table A1.2). Where nest fate could be determined, mink and fox were responsible for depredating more
Fig. 3. Occupancy estimates for red foxes (Vulpes vulpes), mink (Neovison vison) when foxes were absent, and mink when foxes were present during the piping plover (Charadrius melodus) breeding season in New Jersey, USA, 2015-2017, using predictions from a Bayesian two-species occupancy model at 0 $\mathrm{m}$ from the dune based on predator track survey data $(\mathrm{N}=90$ plots, $n=24$ surveys). Symbols represent means, whiskers represent 95\% Bayesian credible intervals.

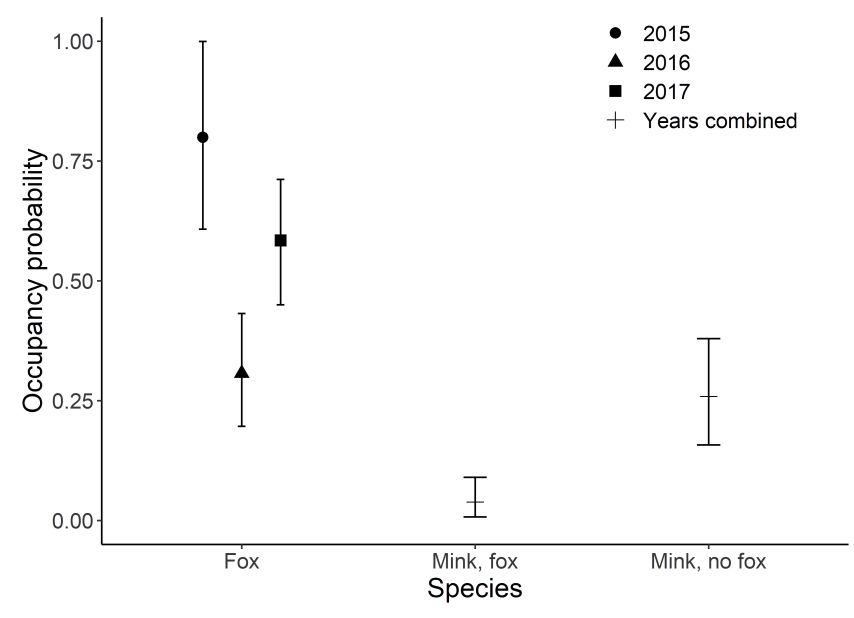

Table 2. Summary statistics for posterior distributions of parameter estimates for a Bayesian two-species occupancy model of red fox (Vulpes vulpes) and American mink (Neovison vison) from predator tracking surveys in New Jersey, USA, 2015-2017. Occupancy parameters are on the logit scale, detection is on the probability scale.

\begin{tabular}{|c|c|c|c|c|c|}
\hline & Parameter & Mean & $\mathrm{SD}$ & $\begin{array}{c}2.5 \% \\
\text { Quantile }\end{array}$ & $\begin{array}{c}97.5 \% \\
\text { Quantile }\end{array}$ \\
\hline \multicolumn{6}{|l|}{ Intercepts } \\
\hline & Fox occupancy & 1.77 & 1.60 & 0.44 & 7.19 \\
\hline & Mink occupancy & -1.08 & 0.30 & -1.68 & -0.49 \\
\hline & Fox detection $^{\dagger}$ & 0.33 & 0.02 & 0.29 & 0.38 \\
\hline & Mink detection $^{\dagger}$ & 0.28 & 0.04 & 0.20 & 0.35 \\
\hline \multicolumn{6}{|l|}{$\begin{array}{l}\text { Fox occupancy } \\
\text { coefficient }\end{array}$} \\
\hline & Mink occupancy & -2.32 & 0.72 & -3.89 & -1.06 \\
\hline \multicolumn{6}{|l|}{ Year coefficients } \\
\hline & $\begin{array}{l}\text { Fox occupancy, } \\
2016\end{array}$ & -2.60 & 1.62 & -8.02 & -1.10 \\
\hline & $\begin{array}{l}\text { Fox occupancy, } \\
2017\end{array}$ & -1.42 & 1.62 & -6.78 & 0.06 \\
\hline \multicolumn{6}{|l|}{ Dune coefficient } \\
\hline & Fox occupancy & -0.28 & 0.22 & -0.74 & 0.14 \\
\hline
\end{tabular}

nests than any other predators (Fig. 4). Moreover, racoons (Procyon lotor), opossums (Didelphis virginiana), and skunks (Mephitis mephitis) only depredated nests at sites where foxes were absent (Fig. 4). Exclosures had a significant positive effect on nest survival (Table 3). Nest predation was lowest for nests that were exclosed at sites with foxes, although variability was high for all categories (Fig. 5; Fig. A1.2). The presence of foxes at a site had 
Fig. 4. Number of depredated nests of piping plovers (Charadrius melodus) by various predator species at study sites where red foxes (Vulpes vulpes) were present and sites where foxes were absent during the nest incubation period [4 May-28 June] in New Jersey, USA, 2015-2017. Study sites are labeled as follows: BALI, Barnegat Lighthouse States Park; HOLG,

Holgate Unit, E.B. Forsythe NWR; NBNA, North Brigantine Natural Area; MWMA, Malibu Beach Wildlife Management Area; AVDU, Avalon-Dunes; SHPT, Stone Harbor Point; NOWI, North Wildwood; CMPSP, Cape May Point State Park. Predator species as evidenced by tracks at the nest bowl included: American Oystercatcher, Haematopus palliatus (AMOY); American Crow, Corvus brachyrhynchos (Crow), red fox (Fox); American mink, Neovison vison (Mink); Virginia opossum, Didelphis virginiana (Opossum); Raccoon, Procyon lotor; striped skunk, Mephitis mephitis (Skunk), and unknown predators.

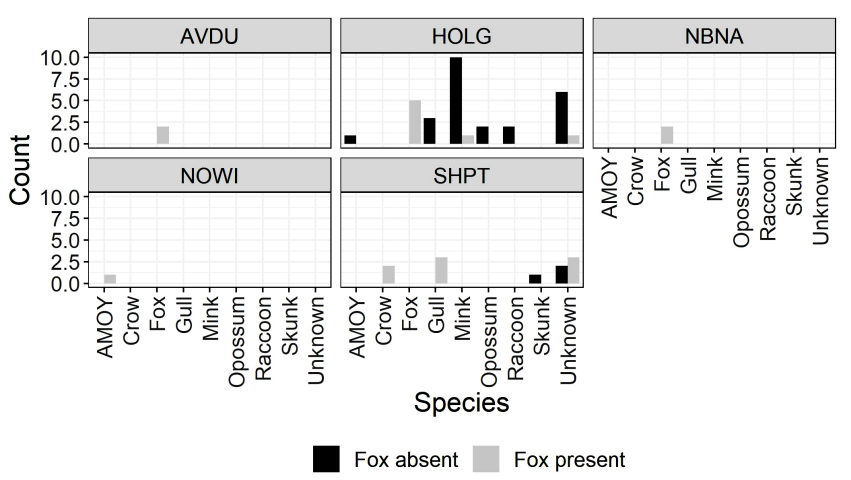

Fig. 5. Nest predation posterior probability density for piping plover (Charadrius melodus) nests at sites where red foxes (Vulpes vulpes) were present (fox) and where foxes were absent (no fox) with (Ex) and without (Unex) nest exclosures in New Jersey, USA, 2015-2017. Dashed lines represent mean estimates, and the width of each distribution represents the variability around the mean estimate.

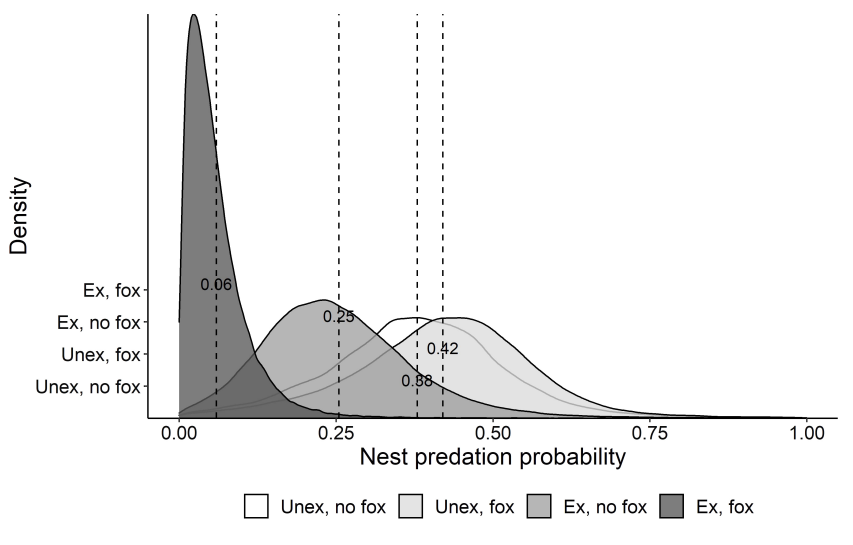

Table 3. Summary statistics for posterior distributions of parameter estimates for multinomial logistic exposure piping plover (Charadrius melodus) nest fate model incorporating raw red fox (Vulpes vulpes) detection/non-detection status from predator tracking surveys, New Jersey, USA, 2015-2017.

\begin{tabular}{|c|c|c|c|c|c|}
\hline & Parameter & Mean & $\mathrm{SD}$ & $\begin{array}{c}2.5 \% \\
\text { Quantile }\end{array}$ & $\begin{array}{c}97.5 \% \\
\text { Quantile }\end{array}$ \\
\hline \multicolumn{6}{|l|}{ Intercepts } \\
\hline & Predation $^{\dagger}$ & -4.19 & 0.59 & -5.61 & -3.30 \\
\hline & Predation, AVDU & -4.05 & 0.58 & -5.32 & -2.96 \\
\hline & Predation, BALI & -4.92 & 1.39 & -8.53 & -3.48 \\
\hline & Predation, HOLG & -4.13 & 0.25 & -4.65 & -3.66 \\
\hline & Predation, MWMA & -4.60 & 1.24 & -8.00 & -3.11 \\
\hline & Predation, NBNA & -4.17 & 0.62 & -5.59 & -3.05 \\
\hline & Predation, NOWI & -3.82 & 0.81 & -5.42 & -2.06 \\
\hline & Predation, SHPT & -3.65 & 0.38 & -4.39 & -2.93 \\
\hline & Flooding & -5.18 & 0.22 & -5.63 & -4.77 \\
\hline & Abandonment & -6.57 & 0.88 & -8.72 & -5.22 \\
\hline \multicolumn{6}{|l|}{$\begin{array}{l}\text { Exclosure } \\
\text { coefficient }\end{array}$} \\
\hline & Predation & -0.47 & 0.44 & -1.38 & 0.38 \\
\hline & Abandonment & 1.20 & 1.04 & -0.54 & 3.60 \\
\hline \multicolumn{6}{|l|}{$\begin{array}{l}\text { Fox presence } \\
\text { coefficient }\end{array}$} \\
\hline & Predation & 0.18 & 0.34 & -0.49 & 0.86 \\
\hline & Abandonment & 0.25 & 1.17 & -1.97 & 2.84 \\
\hline \multicolumn{6}{|l|}{$\begin{array}{l}\text { Interaction } \\
\text { coefficient }\end{array}$} \\
\hline & Predation & -2.02 & 0.97 & -4.11 & -0.26 \\
\hline & Abandonment & -0.28 & 1.36 & -3.33 & 2.24 \\
\hline \multicolumn{6}{|l|}{$\begin{array}{l}\text { Random site } \\
\text { effect SD }\end{array}$} \\
\hline & Predation, intercept & 0.78 & 0.77 & 0.02 & 2.83 \\
\hline
\end{tabular}

${ }^{\top}$ Random site effect hyperparameter

no effect on nest abandonment probability at exclosed or unexclosed nests (Table 3). However, the point estimate for abandonment was twice as great for exclosed nests as unexclosed nests (unexclosed, foxes absent $[0.04\{95 \% \mathrm{BCI}=0.01,0.12\}]$; unexclosed, foxes present $[0.05\{0.01,0.14\}$; exclosed, foxes absent $[0.12\{0.04,0.25\}$; exclosed, foxes present $[0.13\{0.05,0.25\}]$; Fig A1.3).

\section{DISCUSSION}

Our results support the hypothesis that fox removal initiates competitive release of the American mink, a mesopredator, in southern New Jersey, USA and that the phenomenon may have consequences for nest survival of a ground-nesting bird, the Piping Plover. When the dominant predator species in our system was removed from the landscape, a smaller-bodied mesopredator was more likely to be present, which depredated plover nests during our study period (Fig. 4). These findings are in accord with those of Carlsson et al. (2010) in Sweden, who found that mink populations tripled as fox populations declined due to an outbreak of sarcoptic mange, and then subsequently decreased as foxes recovered. Additionally, Crabtree and Wolfe (1988) found that nest predation rates of waterfowl by predators other than skunks, which were the major nest predator, was greater in experimental areas where skunks were removed than in areas where skunks were not removed further suggesting a complex relationship among predators on the landscape. In areas managed 
for endangered species, stable top predator populations may thus contribute to management objectives by restricting mesopredator access to prey populations.

Exclosures are a common management practice, and the routine use of exclosures has reduced egg predation in all parts of the Piping Plover breeding range (USFWS 2020). Their effectiveness can be attributed to most predators being unable to enter inside the exclosure, which allows eggs to be safely incubated, whereas predators such as mink, long-tailed weasels (Mustela frenata) (Nol and Brooks 1982), striped skunks, and Atlantic ghost crabs (Ocypode quadrata) are small enough to enter into the exclosure and depredate nests. Our study found that the complete removal of red foxes from a site increased the presence of mink, and nest predation rates increased for exclosed nests at sites where foxes were absent. Therefore, our findings suggest that wildlife managers may be able to exploit top predators (such as red foxes) by leaving them in the system to limit mesopredator populations then continue to use exclosures to decrease predation pressures on endangered and threatened species. Exclosures can, however, increase nest abandonment rates, likely due to predation of incubating adults by raptors that have learned to associate exclosures with prey (Murphy et al. 2003, Niehaus et al. 2004, Neuman et al. 2004, Hardy and Colwell 2008, Barber et al. 2010, Roche et al. 2010, Darrah et al. 2018). In our study, we found that abandonment rates more than doubled with exclosure use, although the effect was not significant likely due to the small sample size of abandoned nests. Because shorebird population growth rates are often sensitive to changes in adult survival (Melvin and Gibbs 1996, Larson et al. 2002, Sandercock et al. 2005, Robinson 2020), the most problematic effect of exclosure use is the potential for increased predation of incubating adults. The exclusive use of exclosures as a management tool may therefore be impractical at sites where abandonment rates are high (HOLG; Darrah et al. 2020). In order to better understand the demographic trade-off between adult survival and nest success, we recommend the results of our study be incorporated into population viability analyses to estimate the probability of persistence under a range of predation management scenarios.

If lethal predator removal has been identified as a management strategy due to concerns about high nest predation rates, especially due to red foxes, creating a strategic, repeatable, and transparent process for implementing predation management is necessary. Attempting to remove all individuals in a speciesspecific approach may lead to mesopredator release; however, an alternative strategy may be to target problem individuals to help control predation effects. Sanz-Aguilar et al. (2009) found that selectively removing only 16 yellow-legged gulls (Larus michahellis) over a 3-year period led to an increase in breeding success of European storm petrels (Hydrobates pelagicus), demonstrating that the removal of specific individuals can be an effective way to improve nesting success. This strategy, however, can be time-intensive as the effort involved with identifying which individuals are targeting imperiled prey species and then removing those individuals may be substantial. Another alternative might be to identify sites with high quality habitat for a prey species that operate as sources of emigrants, then allocate predator removal resources to source sites to conduct extensive, on-going removal of all predator species and maximize prey species reproductive output. Smith et al. (2010) found a significant increase in breeding bird population sizes when all predators were removed from a site rather than removing only a subset. Ultimately, creating a strategic formula for allocating resources for predation management might help to maximize reproductive output for Piping Plovers.

Considerable resources are expended to manage predator populations of endangered and threatened species to improve conservation outcomes; however, the management action to remove predators that threaten endangered species recovery has not been thoroughly subjected to randomized, experimental tests of effectiveness. One way to examine the effectiveness of predator removal would be to evaluate nesting success at sites where predator removal varies throughout space and time. While all red foxes were removed from HOLG and SHPT during periods of our study (NJENSP, personal communication) giving the opportunity to observationally test the mesopredator release hypothesis, the goal of the predator removal program was to protect beach-nesting birds at each of our study areas, and sites were not randomly chosen to conduct predator removal. We encourage further research directed at examining the efficacy of this management action as predator removal can result in unforeseen consequences. Our results highlight the importance of understanding predator community interactions in developing management strategies to achieve conservation goals, especially in the case of species recovery.

Our study found that the complete removal of fox increased the presence of mink, and nest predation rates increased for exclosed nests at sites where foxes were absent; nevertheless, our results should be considered in light of some limitations. Our study did not follow a manipulative experimental design with proper randomization and replication. In our observational study, foxes were completely removed at only two of our study sites and only during a portion of the study period. While this allowed us to test the mesopredator release hypothesis for American mink at a site where red foxes were completely removed from the system (HOLG), the release of mink may not occur at all sites throughout the Piping Plover breeding range when foxes are removed from the system. While we lacked data to evaluate the potential for mesopredator release for other species, when foxes were completely removed from SHPT, we observed an increase in both skunk activity and in predation rates by skunks suggesting that foxes may also suppress other types of mesopredators. Moreover, we documented depredation by other mesopredators such as opossums and raccoons only when foxes were not present. The consequences of predator removal, however, may vary across the Piping Plover breeding range depending on the predator community and, evaluating the potential trophic level interactions prior to implementing a predator removal program might achieve more beneficial results to beach-nesting bird populations.

Ultimately, if mesopredator release does not occur when apex predators are removed from the landscape, then removing a top predator species should help to ease predation pressures; however, if mesopredator release does occur, then a thorough and more comprehensive predation management strategy that targets multiple interacting species may be necessary to promote reproductive success for endangered species. The potential trophic interactions between non-mammalian predators add further complexity, demonstrating the need for additional research. 
Responses to this article can be read online at: https://www.ace-eco.org/issues/responses.php/1806

\section{Acknowledgments:}

This study was funded by National Fish and Wildlife Foundation (NFWF), U.S. Fish and Wildlife Service (USFWS), and New Jersey Non-game and Endangered Species Program (NJENSP). All animal-handling protocols were approved by the SUNY-ESF IACUC (\#190303). Trapping, banding, and research efforts were approved by the Bird Banding Laboratory (BBL permit \# 23736), USFWS (\#TE35010D-0) and NJENSP (permit \# SC 2019112). All authors helped conceive the ideas for the paper and designed the methodology. Michelle L. Stantial conducted the fieldwork, Michelle L. Stantial analyzed the data, Michelle L. Stantial and Jonathan B. Cohen led the writing of the paper. All authors gave final approval for publication. We thank Christina "Kashi" Davis, Emily Heiser, and Todd Pover for logistical and field support. Finally, we thank Rebeca Linhart and Tyler Tomassone for assistance in the field.

\section{LITERATURE CITED}

Balser, D. S., H. H. Dill, and H. K. Nelson. 1968. Effect of predator reduction on waterfowl nesting success. Journal of Wildlife Management 32:669-682. https://doi.org/10.2307/3799541

Barber, C., A. Nowak, K. Tulk, and L. Thomas. 2010. Predator exclosures enhance reproductive success but increase adult mortality of Piping Plovers (Charadrius melodus). Avian Conservation and Ecology 5(2):6. https://doi.org/10.5751/ ACE-00419-050206

Berry, L., and E. Taisacan. 2008. Nest success and nest predation of the endangered Rota white-eye (Zosterops rotensis). Wilson Journal of Ornithology 120:618-619. https://doi.org/10.1676/07-141.1

Bino, G., A. Dolev, D. Yosha, A. Guter, R. King, D. Saltz, and S. Kark. 2010. Abrupt spatial and numerical responses of overabundant foxes to a reduction in anthropogenic resources. Journal of Applied Ecology 47:1262-1271. https://doi.org/10.1111/ j.1365-2664.2010.01882.x

Boarman, W. I. 2003. Managing a subsidized predator population: Reducing common raven predation on desert tortoises. Environmental Management 32:205-217. https://doi. org/10.1007/s00267-003-2982-X

Cairns, E. 1977. Breeding biology and behaviour of the piping plover Charadrius melodus in southern Nova Scotia. M.S. Thesis, Dalhousie University, Halifax, Nova Scotia.

Carlsson, N. O. L., J. M. Jeschke, N. Holmqvist, and J. Kindberg. 2010. Long-term data on invaders: when the fox is away, the mink will play. Biological Invasions 12:633-641. https://doi.org/10.1007/ s10530-009-9470-Z

Chalfoun, A. D., F. R. Thompson, and M. J. Ratnaswamy. 2002. Nest predators and fragmentation: a review and meta-analysis. Conservation Biology 16:306-318. https://doi.org/10.1046/ j.1523-1739.2002.00308.x
Clark, R. G., D. E. Meger, and J. B. Ignatiuk. 1995. Removing American crows and duck nesting success. Canadian Journal of Zoology 73:518-522. https://doi.org/10.1139/z95-059

Cohen, J. B., L. M. Houghton, and J. D. Fraser. 2009. Nesting density and reproductive success of Piping Plovers in response to storm- and human-created habitat changes. Wildlife Monographs 173:1-24. https://doi.org/10.2193/2007-553

Côté, I. M., and W. J. Sutherland. 1997. The effectiveness of removing predators to protect bird populations. Conservation Biology 11:395-405. https://doi.org/10.1046/j.1523-1739.1997.95410. $\mathrm{x}$

Crabtree, R. L., and M. L. Wolfe. 1988. Effects of alternate prey on skunk predation of waterfowl nests. Wildlife Society Bulletin (1973-2006) 16:163-169.

Darrah, A. J., J. B. Cohen, and P. M. Castelli. 2018. A Bayesian multinomial logistic exposure model for estimating probabilities of competing sources of nest failure. Ibis 160:23-35. https://doi. org/10.1111/ibi.12510

Darrah, A. J., J. B. Cohen, and P. M. Castelli. 2020. A decision support tool to guide the use of nest exclosures for Piping Plover conservation. Wildlife Society Bulletin 44:480-492. https://doi. org/10.1002/wsb.1115

Donadio, E., and S. W. Buskirk. 2006. Diet, morphology, and interspecific killing in Carnivora. The American Naturalist 167:524-536. https://doi.org/10.1086/501033

Elbroch, M. 2003. Mammal Tracks \& Sign, 1st edition. Stackpole Books, Mechanicsburg, PA.

Estelle, V. B., T. J. Mabee, and A. H. Farmer. 1996. Effectiveness of predator exclosures for Pectoral Sandpiper nests in Alaska. Journal of Field Ornithology 67:447-452.

Fischer, J. D., S. H. Cleeton, T. P. Lyons, and J. R. Miller. 2012. Urbanization and the predation paradox: The role of trophic dynamics in structuring vertebrate communities. BioScience 62:809-818. https://doi.org/10.1525/bio.2012.62.9.6

Gelman, A. 2004. Parameterization and Bayesian modeling. Journal of the American Statistical Association 99:537-545. https://doi.org/10.1198/016214504000000458

Gorga, C. 2012. Ecology of the American mink \& the potential impact on species of concern in Cape Romain National Wildlife Refuge, South Carolina. Clemson University, Clemson, SC. [online] URL: https://tigerprints.clemson.edu/all_theses/1391

Gosselink, T. E., T. R. Van Deelen, R. E. Warner, and M. G. Joselyn. 2003. Temporal habitat partitioning and spatial use of coyotes and red foxes in East-Central Illinois. The Journal of Wildlife Management 67:90-103. https://doi.org/10.2307/3803065

Hardy, M. A., and M. A. Colwell. 2008. The impact of predator exclosures on Snowy Plover nesting success: a seven-year study. Wader Study Group Bulletin 115:161-166.

Hecht, A., and S. M. Melvin. 2009. Expenditures and effort associated with recovery of breeding Atlantic Coast piping plovers. Journal of Wildlife Management 73:1099-1107. https:// doi.org/10.2193/2008-061 
Avian Conservation and Ecology 16(1): 8

Holt, A. R., Z. G. Davies, C. Tyler, and S. Staddon. 2008. Metaanalysis of the effects of predation on animal prey abundance: evidence from UK vertebrates. PLOS ONE 3:e2400. https://doi. org/10.1371/journal.pone.0002400

Johnson, D. H., and A. B. Sargeant. 1977. Impact of red fox predation on the sex ratio of prairie mallards. Page Wildlife Research Report. U.S. Fish and Wildlife Service, Jamestown, ND.

Kellner, K. 2017. jagsUI: A wrapper around "rjags" to streamline “JAGS” analyses. [online] URL: https://CRAN.R-project.org/ package $=$ jagsUI.

Kendall, W. L., J. E. Hines, J. D. Nichols, and E. H. C. Grant. 2013. Relaxing the closure assumption in occupancy models: staggered arrival and departure times. Ecology 94:610-617. https://doi.org/10.1890/12-1720.1

Kuo, L., and B. Mallick. 1998. Variable selection for regression models. Sankhyâ: Indian Journal of Statistics, Series B (1960-2002) 60:65-81.

Larivière, S., and M. Pasitschniak-Arts. 1996. Vulpes vulpes. Mammalian Species:1-11. https://doi.org/10.2307/3504236

Larson, M. A., M. R. Ryan, and R. K. Murphy. 2002. Population viability of piping plovers: effects of predator exclusion. Journal of Wildlife Management 66:361-371. https://doi.org/10.2307/3803169

Lavers, J. L., C. Wilcox, and C. Josh Donlan. 2010. Bird demographic responses to predator removal programs. Biological Invasions 12:3839-3859. https://doi.org/10.1007/s10530-010-9776$\mathrm{x}$

Letnic, M., E. G. Ritchie, and C. R. Dickman. 2012. Top predators as biodiversity regulators: the dingo Canis lupus as a case study. Biological Reviews 87(2):390-413. https://doi.org/10.1111/ j.1469-185X.2011.00203.x

Lima, S. L. 1998. Nonlethal effects in the ecology of predatorprey interactions. BioScience 48:25-34. https://doi.org/10.2307/1313225

Link, W. A., and R. J. Barker. 2006. Model weights and the foundations of multimodel inference. Ecology 87:2626-2635.

Littlefield, C. D. 2003. Sandhill crane nesting success and productivity in relation to predator removal in southeastern Oregon. Wilson Journal of Ornithology 115:263-269. https://doi. org/10.1676/02-108

Marzluff, J. M., and E. Neatherlin. 2006. Corvid response to human settlements and campgrounds: Causes, consequences, and challenges for conservation. Biological Conservation 130:301-314. https://doi.org/10.1016/j.biocon.2005.12.026

Melvin, S. M., and J. P. Gibbs. 1996. Viability analysis for the Atlantic Coast Population of Piping Plovers. U.S. Fish and Wildlife Service, Hadley, MA.

Melvin, S. M., L. H. MacIvor, and C. R. Griffin. 1992. Predator exclosures: A technique to reduce predation at piping plover nests. Wildlife Society Bulletin 20:143-148.

Murphy, R. K., I. M. G. Michaud, D. R. C. Prescott, J. S. Ivan, B. J. Anderson, and M. L. French-Pombier. 2003. Predation on adult piping plovers at predator exclosure cages. Waterbirds
26:150-155. https://doi.org/10.1675/1524-4695(2003)026[0150: POAPPA]2.0.CO;2

Myers, R. A., J. K. Baum, T. D. Shepherd, S. P. Powers, and C. H. Peterson. 2007. Cascading effects of the loss of apex predatory sharks from a coastal ocean. Science 315(5820): 1846-50. https:// doi.org/10.1126/science. 1138657

Neuman, K. K., G. W. Page, L. E. Stenzel, J. C. Warriner, and J. S. Warriner. 2004. Effect of mammalian predator management on Snowy Plover breeding success. Waterbirds 27:257-263. https:// doi.org/10.1675/1524-4695(2004)027[0257:EOMPMO]2.0.CO;2

Niehaus, A. C., D. R. Ruthrauff, and B. J. McCaffery. 2004. Response of predators to Western sandpiper nest exclosures. Waterbirds 27:79-82. https://doi.org/10.1675/1524-4695(2004) 0270079:ROPTWS]2.0.CO;2

NJDEP/OIRM/BGIS. 2015. Land Use/Land Cover 2012 Update. NJ Department of Environmental Protection (NJDEP), Trenton, NJ. [online] URL: https://www.nj.gov/dep/gis/digidownload/ metadata/lulc12/Land_lu_2012_hu02020007.html

Nol, E., and R. J. Brooks. 1982. Effects of predator exclosures on nesting success of killdeer. Journal of Field Ornithology 53:263-268.

NYS DEC. 1951. A study of fox control as a means of increasing pheasant abundance. New York State Conservation Department, Division of Fish and Game, Research Series 3.

Palomares, F., P. Gaona, P. Ferreras, and M. Delibes. 1995. Positive effects on game species of top predators by controlling smaller predator populations: An example with lynx, mongooses, and rabbits. Conservation Biology 9:295-305. https://doi. org/10.1046/j.1523-1739.1995.9020295.x

Patterson, M. E., J. D. Fraser, and J. W. Roggenbuck. 1991. Factors affecting piping plover productivity on Assateague Island. Journal of Wildlife Management 55:525-531. https://doi. org/10.2307/3808985

Peeples, J. W. 2001. The feasibility of re-establishing wild mink in the northern coastal marshes of South Carolina. Clemson University, Clemson, SC.

Plummer, M. 2013. JAGS - Just Another Gibbs Sampler. [online] URL: http://mcmc-jags.sourceforge.net/

R Core Team. 2019. R: A language and environment for statistical computing. Foundation for Statistical Computing, Vienna, Austria.

Rayner, M. J., M. E. Hauber, M. J. Imber, R. K. Stamp, and M. N. Clout. 2007. Spatial heterogeneity of mesopredator release within an oceanic island system. Proceedings of the National Academy of Sciences 104:20862-20865. https://doi.org/10.1073/ pnas.0707414105

Richmond, O. M. W., J. E. Hines, and S. R. Beissinger. 2010. Twospecies occupancy models: a new parameterization applied to cooccurrence of secretive rails. Ecological Applications 20:2036-2046. https://doi.org/10.1890/09-0470.1

Robinson, S. G. 2020, March. Piping plover habitat and demography following storm-induced and engineered landscape change. Dissertation, Virginia Tech, Blacksburg, VA. [online] URL: https://vtechworks.lib.vt.edu/handle/10919/97725 
Roche, E. A., T. W. Arnold, and F. J. Cuthbert. 2010. Apparent nest abandonment as evidence of breeding-season mortality in Great Lakes piping plovers (Charadrius melodus). Auk 127:402-410. https://doi.org/10.1525/auk.2009.09034

Rogers, C. M., and M. J. Caro. 1998. Song sparrows, top carnivores and nest predation: a test of the mesopredator release hypothesis. Oecologia 116:227-233. https://doi.org/10.1007/ s004420050583

Rota, C. T., M. A. R. Ferreira, R. W. Kays, T. D. Forrester, E. L. Kalies, W. J. McShea, A. W. Parsons, and J. J. Millspaugh. 2016. A multispecies occupancy model for two or more interacting species. Methods in Ecology and Evolution 7:1164-1173. https:// doi.org/10.1111/2041-210X.12587

Russel, J. C., V. Lecomte, Y. Dumont, and M. Le Corre. 2009. Intraguild predation and mesopredator release effect on longlived prey. Ecological Modelling 220:1098-1104. https://doi. org/10.1016/j.ecolmodel.2009.01.017

Sandercock, B. K., T. Székely, and A. Kosztolányi. 2005. The effects of age and sex on the apparent survival of Kentish plovers breeding in southern Turkey. Condor 107:583-596. https://doi. org/10.1093/condor/107.3.583

Sanz-Aguilar, A., A. Martínez-Abraín, G. Tavecchia, E. Mínguez, and D. Oro. 2009. Evidence-based culling of a facultative predator: efficacy and efficiency components. Biological Conservation 142:424-431. https://doi.org/10.1016/j.biocon.2008.11.004

Shaffer, T. L. 2004. A unified approach to analyzing nest success. Auk 121:526-540.

Smith, R. K., A. S. Pullin, G. B. Stewart, and W. J. Sutherland. 2010. Effectiveness of predator removal for enhancing bird populations. Conservation Biology 24:820-829. https://doi. org/10.1111/j.1523-1739.2009.01421.x

Soulé, M. E., D. T. Bolger, A. C. Alberts, J. Wright, M. Sorice, and S. Hill. 1988. Reconstructed dynamics of rapid extinctions of chaparral-requiring birds in urban habitat islands. Conservation Biology 2:75-92.

Sovada, M. A., A. B. Sargeant, and J. W. Grier. 1995. Differential effects of coyotes and red foxes on duck nest success. Journal of Wildlife Management 59:1-9. https://doi.org/10.2307/3809108

Stantial, M. L., J. B. Cohen, A. J. Darrah, S. Farrell, and B. Maslo. 2020. Red fox use of landscapes with nesting shorebirds. Journal of Wildlife Management:1-12. https://doi.org/10.1002/jwmg.21949

U.S. Fish and Wildlife Service (USFWS). 1996. Piping Plover (Charadrius melodus) Atlantic Coast Population Revised Recovery Plan. U.S. Fish and Wildlife Service, Hadley, MA. [online] URL: http://omnilearn.net/esacourse/pdfs/piping_plover_recovery_plan96. pdf
U.S. Fish and Wildlife Service (USFWS). 2020. Piping Plover (Charadrius melodus) 5-Year Revew: Summary and Evaluation. U.S. Fish and Wildlife Service, Hadley, MA. [online] URL: https://ecos.fws.gov/docs/five_year_review/doc6378.pdf

Vanderwerf, E. A. 2012. Evolution of nesting height in an endangered Hawaiian forest bird in response to a non-native predator. Conservation Biology 26:905-911. https://doi.org/10.1111/ j.1523-1739.2012.01877.x

Vickery, P. D., M. L. Hunter, and J. V. Wells. 1992. Evidence of incidental nest predation and its effects on nests of threatened grassland birds. Oikos 63:281-288. https://doi.org/10.2307/3545389

Wagner, F. H., C. D. Besadny, and C. Kabat. 1965. Population ecology and management of Wisconsin pheasants. Technical bulletin, Game Management Division, Wisconsin Conservation Department. [online] URL: https://dnr.wi.gov/files/PDF/pubs/ ss/SS0034.pdf
Editor-in-Chief: Keith A.Hobson Subject Editor: Erica Nol

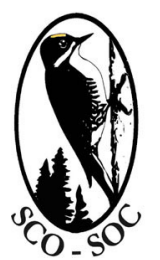

Sponsored by the Society of Canadian Ornithologists and Birds Canada

Parrainée par la Société des ornithologistes du Canada et Oiseaux Canada

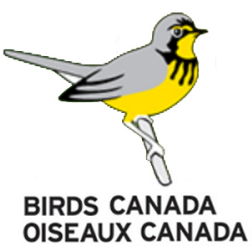


APPENDIX 1. Supplementary tables and figures

Table A1. Possible statuses of piping plover nests during each nest check in New Jersey, USA, 2015-2017.

\begin{tabular}{ll}
\hline Status & Description \\
\hline Active & Nest actively being tended by both adults; incubation observed \\
Hatched & Nest hatched; chicks present \\
Depredated & Nests lost to predation as evidenced by predator tracks at the \\
& nest bowl \\
Overwashed & Nest lost to flooding as evidenced by the high tide line above the \\
& nest bowl, nest bowl no longer visible, and no predator tracks at \\
& the nest \\
Abandoned & Nest inactive; adults not tending eggs; no plover tracks at the \\
& nest bowl; eggs cold \\
Buried & Eggs covered with 3+ inches of sand following a high \\
& windstorm event, evidenced by digging out nest scrape and \\
& finding eggs \\
Unknown & Eggs missing from the nest scrape with no reliable evidence as \\
&
\end{tabular}


Table A2. Sample sizes of nesting attempts and renesting attempts of piping plovers at sites where red foxes were present or absent in New Jersey, USA, 2015-2017.

\begin{tabular}{lrcr}
\hline Event & Fox present & Fox absent & Total \\
\hline Nest attempts & 87 & 90 & 177 \\
Renest attempts & 29 & 35 & 64 \\
\hline
\end{tabular}




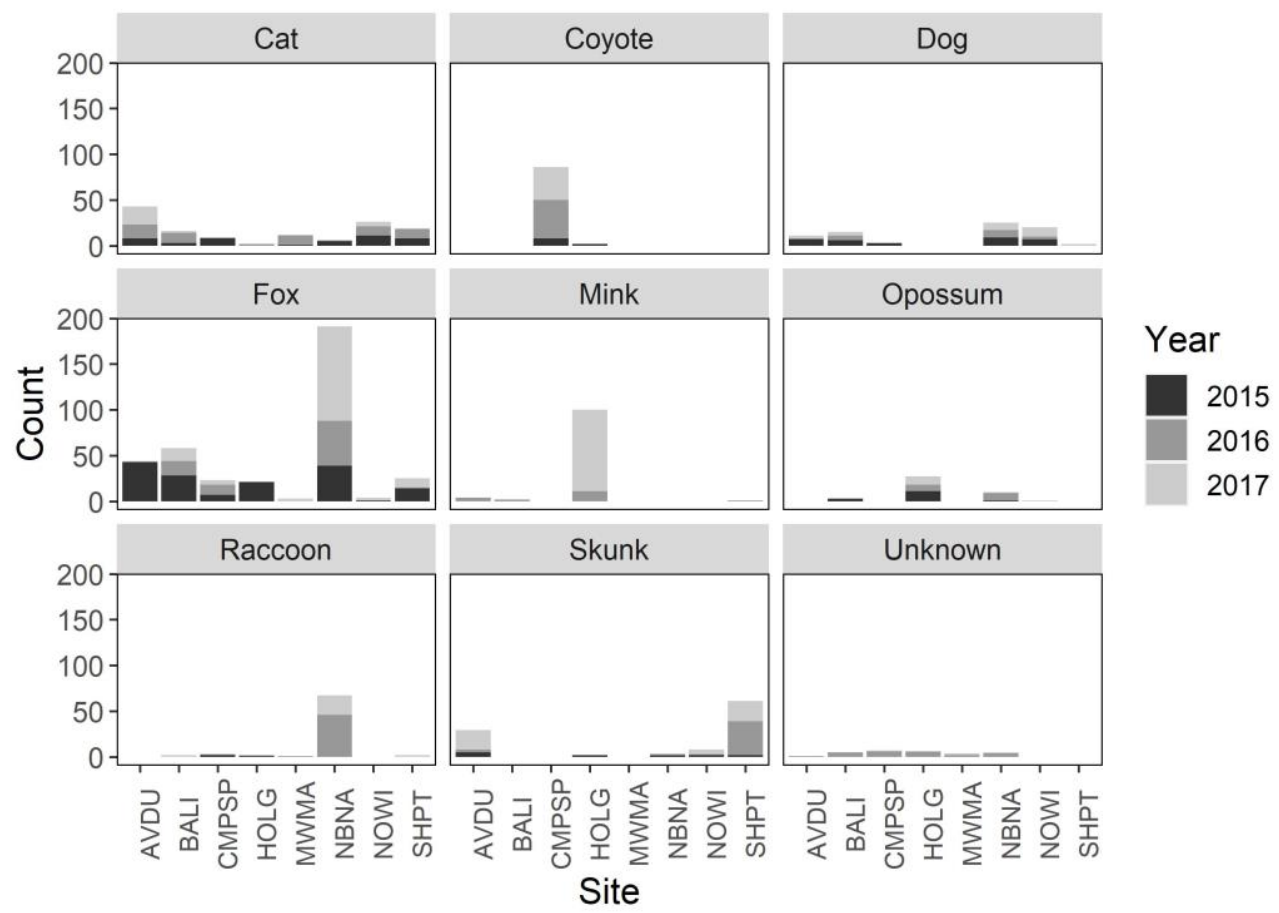

Figure A1. Number of detections of each mammalian predator species at piping plover breeding sites in New Jersey, USA, 2015-2017. Species are as follows: feral cat (Cat, Felis catus); coyote (Canis latrans); domestic dog (Canis lupus familiaris); red fox (Fox, Vulpes vulpes); American mink (Mink, Neovison vison); Virginia opossum (Opossum, Didelphis virginiana); raccoon (Procyon lotor); striped skunk (Skunk, Mephitis mephitis); and unknown mammal (Unknown). Study sites include Barnegat Lighthouse States Park (BALI), Holgate Unit, E.B. Forsythe NWR (HOLG), North Brigantine Natural Area (NBNA), Malibu Beach Wildlife Management Area (MWMA), Avalon-Dunes (AVDU), Stone Harbor Point (SHPT), North Wildwood (NOWI), Cape May Point State Park (CMPSP). 


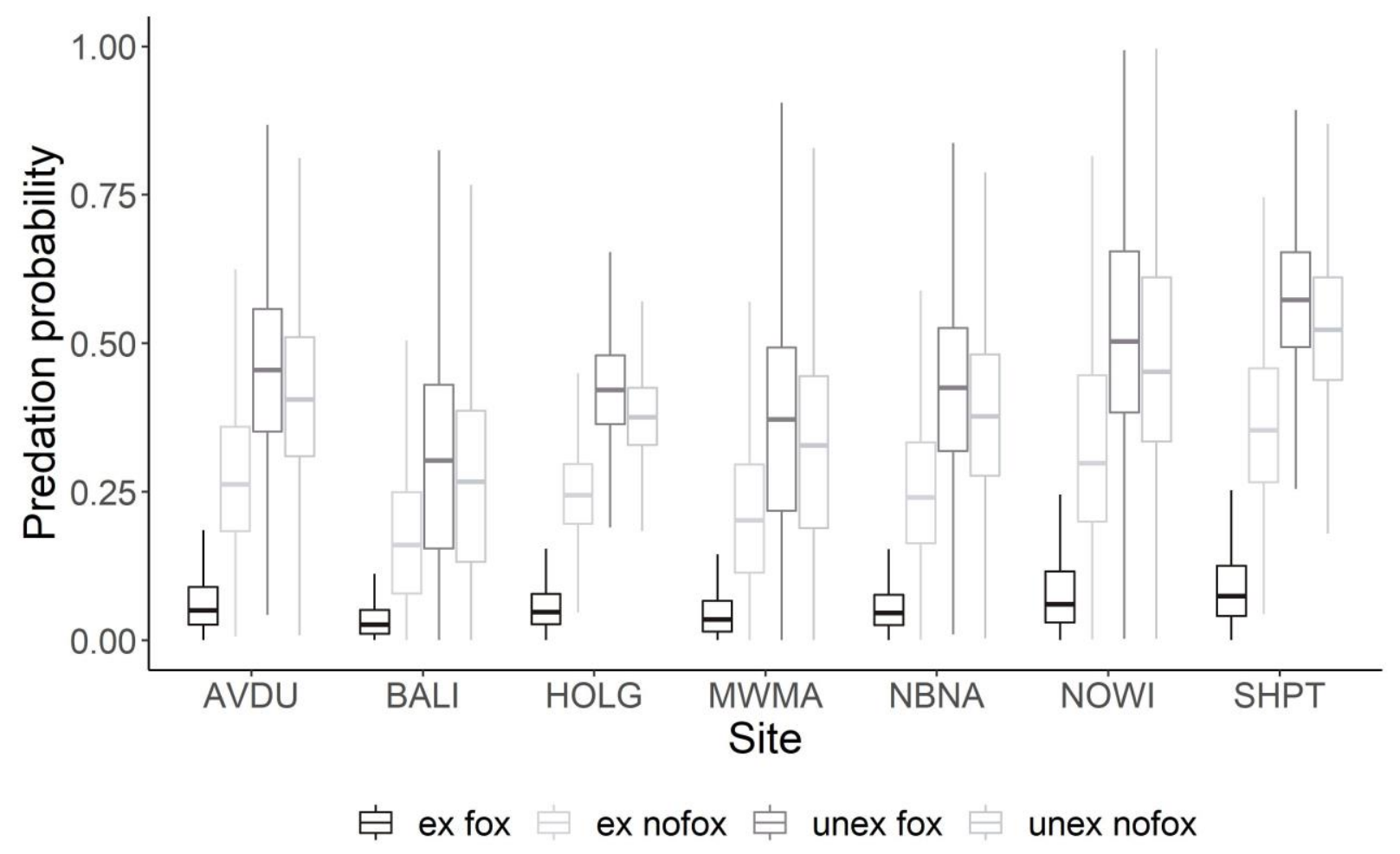

Figure A2. Predation probability for piping plover nests at sites where red foxes were present (fox) and where foxes were absent (nofox) with (ex) and without (unex) nest exclosures in New Jersey, USA, 2015-2017. Study sites are labeled as follows: BALI, Barnegat Lighthouse States Park; HOLG, Holgate Unit, E.B. Forsythe NWR; NBNA, North Brigantine Natural Area; MWMA, Malibu Beach Wildlife Management Area; AVDU, Avalon-Dunes; SHPT, Stone Harbor Point; NOWI, North Wildwood; CMPSP, Cape May Point State Park. Each box represents the inter-quartile range $\left(25^{\text {th }}\right.$ and $75^{\text {th }}$ percentiles) where the center stripe of each box represents the median. The whiskers represent the observation greater than or equal to the 25 th percentile $-1.5 * \mathrm{IQR}$ or the 75 th percentile $+1.5^{*} \mathrm{IQR}$. 


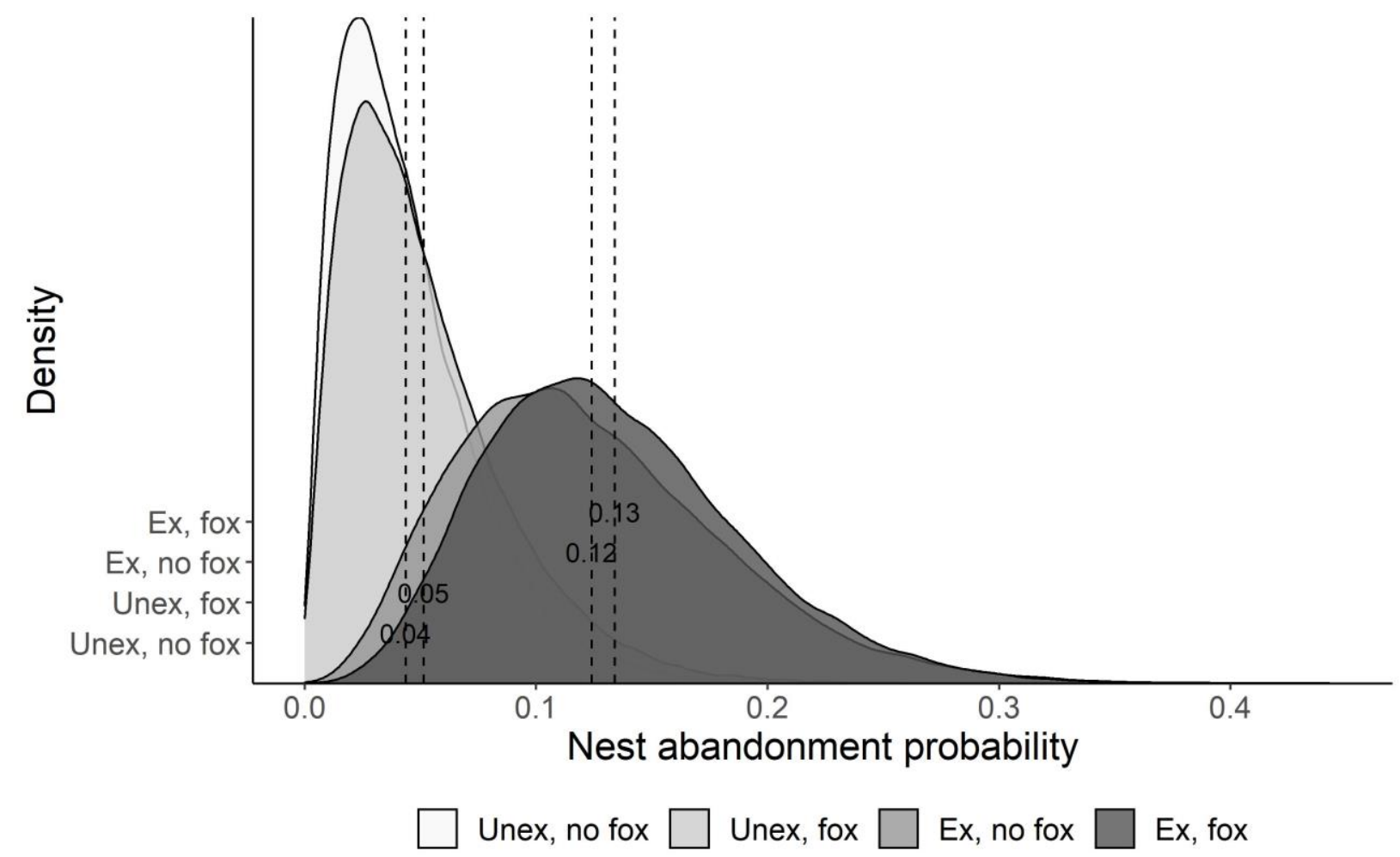

Figure A3. Nest abandonment posterior probability density for piping plover nests at sites where red foxes were present (fox) and where foxes were absent (no fox) with (Ex) and without (Unex) nest exclosures in New Jersey, USA, 2015-2017. Dashed lines represent mean estimates, and the width of each distribution represents the variability around the mean estimate. 